\title{
Aluminum Consumption and Economic Growth Evidence from Rich Countries
}

\section{Journal Article}

Author(s):

Jaunky, Vishal Chandr

Publication date:

2012-06

Permanent link:

https://doi.org/10.3929/ethz-b-000059044

Rights / license:

In Copyright - Non-Commercial Use Permitted

Originally published in:

Natural resources research 21(2), https://doi.org/10.1007/s11053-012-9171-7 


\title{
Aluminum Consumption and Economic Growth: Evidence from Rich Countries
}

\author{
Vishal Chandr Jaunky ${ }^{1,2}$
}

Received 4 September 2011; accepted 7 February 2012 Published online: 9 March 2012

The article attempts to test the aluminum consumption-economic growth nexus for 20 rich economies for the period 1970-2009. Various panel data unit root and cointegration tests are applied. The series are found to be integrated of order one and cointegrated, especially after controlling for cross-sectional dependence. Moreover, the Blundell-Bond system generalized methods-of-moments is employed to conduct a panel causality test in a vector errorcorrection mechanism setting. Unidirectional causality running from aluminum consumption to real GDP is uncovered in the short-run, while real GDP is found to Granger-cause aluminum consumption in the long-run. Moreover, a 1\% increase in real GDP generates an increase of $0.44 \%$ in aluminum consumption in the long-run for the whole panel.

KEY WORDS: aluminum consumption, economic growth, panel causality, panel DOLS.

\section{INTRODUCTION}

Aluminum is one of the most important materials used today. Aluminum's strength, lightness, and malleability have led its increased applications in various sectors such as building, transport, and household. Such material is used in the manufacturing of frames, doors, railways, cars, cooking utensils, electrical appliances, etc., and has countless applications. The aluminum industry consists of four main areas of activity: bauxite mining, alumina refining, aluminum smelting, and fabrication/semifabrication of final products. However, the industry is extremely energy-intensive and its activities raise significant environmental concerns such as the creation of greenhouse gases (GHGs). First, using bauxite to

\footnotetext{
${ }^{1}$ Centre for Energy Policy and Economics, ETH Zurich, Zurichbergstrasse 18, 8032, Zurich, Switzerland.

${ }^{2}$ To whom correspondence should be addressed; e-mail: vjaunky@ethz.ch
}

produce alumina involved the discarding of chemical wastes (e.g., caustic soda) in landfills. GHGs and particles from boilers result from the production of alumina (Menzie et al. 2010). The processing of alumina to aluminum metal occurs in smelters via the Hall-Heroult process. This typically involves the dissolving of alumina in a bath of molten cryolite and transmitting an electric current through the solution, via a carbon anode and a carbon-lined metallic cathode. In addition to the enormous amount of electricity consumed, this process leads to the release of significant amounts of GHGs including perfluorocarbons: tetrafluoromethane $\left(\mathrm{CF}_{4}\right)$, hexafluoroethane $\left(\mathrm{C}_{2} \mathrm{~F}_{6}\right)$, and carbon dioxide $\left(\mathrm{CO}_{2}\right)$ emissions (Turton 2002).

The consumption of a metal such as aluminum can be considered intrinsically linked to the level of economic activity. From the policymaker's standpoint, it is vital to address the environmental issues emanating from the manufacture of aluminum and to discern whether any policy prescriptions will adversely affect 
economic activity levels. Furthermore, the price of aluminum necessarily dictates consumption of the material. Imposing a carbon tax scheme on smelters will eventually lead to an increase in aluminum prices as the cost of production rises. This can have an adverse effect on economic growth. This article presents the first study of the link between aluminum consumption and economic growth using panel data from 20 rich countries $^{3}$ over the period of 1970-2009. Demand for aluminum in high-income economies is more substantial than in low- or middle-income ones and any policies dealing with the aluminum industry are bound to have a more significant impact on economic growth and vice versa. Thus far, the literature has focused on cross-sectional or time-series studies. Refined aluminum consumption data are obtained from the World Bureau of Metal Statistics (various years), while those of real gross domestic product (GDP, at constant 2000) are gathered from the World Development Indicators CD-ROM (2011).

The remainder of this article is organized as follows: "Review of Literature" section reviews the literature. "The Testing Framework" section discusses the testing framework, which involves a threestage procedure (Ghosh 2006) to test for any causality between the two variables. In the first stage, various panel unit root tests are performed to identify the order of integration of the two series. Depending on the results of these tests, the second stage consists of investigating any long-run relationship between the two series. Various panel cointegration tests will be conducted. Conditional on the outcome of the second stage, the third stage will consist of carrying out a panel vector error-correction mechanism (VECM)-based causality test using the two-step system generalized methods-of-moments (GMM) approach. The empirical results show strong evidence of a long-run relationship between aluminum consumption and economic growth and, a long-run causal effect of economic growth on aluminum consumption is also uncovered. "Conclusion and Policy Implications" section concludes and discusses the policy implications of this study.

\section{REVIEW OF LITERATURE}

The literature on the link between metal consumption and economic growth remains relatively

\footnotetext{
${ }^{3}$ The time frame and the selection of countries are purely dictated by the availability of data. The rich economies follow the classification of the World Bank (at http://go.worldbank.org/ K2CKM78CC0).
}

sparse. Tilton (1989) analyzes six industrial metals in the OECD, the US, Japan, and the EEC over two periods, 1960-1973 and 1973-1985. Metal consumption in these regions is found to be stimulated by increased economic activity. Roberts (1990) forecasts the US steel consumption up to 2010 using data over the period 1963-1983. He notes the importance of the gross national product in determining metal use. Labson and Crompton (1993) analyze the link between five industrial metals and income for the US, UK, Japan, and OECD for the period of 19601987. However, they offer little evidence to support the presence a long-run link between the two variables.

Recently, Ghosh (2006) has examined cointegration and Granger causality between steel consumption and economic growth in India for the period beginning in 1951-1952 and ending in 20032004 through a vector autoregression (VAR) structure. He does not find evidence of cointegration but he discovers the existence of a unidirectional causal effect of economic growth on steel consumption. Huh (2011) studies the short- and long-run causal links between steel consumption and economic activity in Korea over the period of 1975-2008 using VECM and VAR models. Using disaggregated data, he uncovers a long-run relationship between total steel consumption and GDP. Furthermore, a unidirectional causality running from GDP to total steel consumption is detected. Evidence of a long-run bidirectional causality between flat products consumption and manufacturing GDP is also found. Next, flat products consumption is found to have a long-run relationship with steel-consuming industries such as the automobile, shipbuilding, and fabricated metal product industries, but with mixed causal directions, depending on variable pairs. According to his study, steel and steel-consuming industries are expected to have a significant impact on economic growth.

\section{THE TESTING FRAMEWORK}

To investigate whether economic growth has an impact on aluminum consumption the following reduced-form equation can be estimated:

$$
\mathrm{LALC}_{i t}=\beta_{0}+\beta_{1} \mathrm{LGDP}_{i t}+\varepsilon_{i t}
$$

where $\mathrm{LALC}_{i t}$ denotes the natural logarithm of refined aluminum consumption (in metric tonnes) for country $i$ over year $t$. LGDP $i t$ measures real 
income or economic growth and denotes the natural logarithm of GDP (at constant 2000) for country $i$ and year $t . \beta_{0}$ is the constant term. $\beta_{1}$ illustrates the income elasticity of aluminum consumption for the panel as a whole group of 20 high-income countries. The resulting elasticity may not coincide with the elasticity at individual levels. If $\beta_{1}>1$, this depicts a high responsiveness of aluminum consumption to changes in income. A rise in real GDP leads to a more than proportionate rise in aluminum consumption. Aluminum is deemed to be a luxury good. If $0<\beta_{1}<1$, then a rise in real GDP leads to a less than proportionate rise in aluminum consumption. Aluminum is deemed to be a normal good. If $\beta_{1}<0$, then a rise in real GDP leads to a fall in aluminum consumption. Aluminum is deemed to be an inferior good. $\varepsilon_{i t}$ is the error-term. Table 1 shows the trends of $\mathrm{LALC}_{i t}$ and $\mathrm{LGPD}_{i t}$ over selected years.

\section{Panel Unit Root and Cointegration Tests}

Preliminary tests such as unit root and cointegration tests are necessary before carrying out a panel VECM-based causality test. Practically, most of the panel unit root tests are based on an augmented Dickey-Fuller (ADF 1979) unit root test type:

$$
\Delta y_{i t}=\mu_{i}+\beta_{i} t+\rho y_{i t-1}+\alpha_{i m} \sum_{m=1}^{k_{i}} \Delta y_{i, t-m}+e_{i t}
$$

where $\Delta y_{i t}=y_{i t}-y_{i t-1}, t$ is the time trend, $k$ is the lag length, and $e$ is the error-term. If the null hypothesis $\left(\mathrm{H}_{0}\right)$ is accepted (i.e., $\left.\mathrm{H}_{0}: \hat{\rho}=0\right)$, then the series is non-stationary. The unit root tests used are Levin, Lin, and Chu (LLC 2002), Im, Pesaran, and Shin (IPS 2003), Hadri (2000), Im, Lee, and Tieslau (ILT 2005), and Pesaran (2007) tests. These tests exhibit some statistical shortcomings in terms of size and power properties. To present robust evidence about the order of integration of the series, it is therefore more practical to perform several tests before reaching a conclusion.

Next, if both series are non-stationary and integrated of the same order, panel cointegration tests can be performed. Nyblom and Harvey (NH 2000) put forth a test of common trends where $\mathrm{H}_{0}$ is the stationarity of the series around a deterministic trend, where there exists $k<n$ common trends (where rank $(\Sigma \eta)=k$ ), against the alternative of a random walk component occurrence where there

Table 1. Trends Over Selected Years

\begin{tabular}{|c|c|c|c|c|c|c|c|c|c|c|c|c|}
\hline \multirow[b]{2}{*}{ Countries } & \multicolumn{4}{|c|}{ LALC } & \multicolumn{4}{|c|}{ LGDP } & \multicolumn{4}{|c|}{ LURB } \\
\hline & 1970 & 1995 & 2009 & 1970-2009 & 1970 & 1995 & 2009 & 1970-2009 & 1970 & 1995 & 2009 & 1970-2009 \\
\hline Australia & 11.730 & 12.746 & 12.651 & 12.520 & 25.800 & 26.545 & 27.030 & 26.468 & 0.487 & 0.855 & 1.046 & 0.791 \\
\hline Austria & 11.225 & 11.918 & 12.207 & 11.923 & 25.157 & 25.829 & 26.109 & 25.738 & 4.501 & 4.569 & 4.620 & 4.550 \\
\hline Belgium & 12.072 & 12.724 & 12.516 & 12.612 & 25.421 & 26.031 & 26.287 & 25.947 & 5.763 & 5.813 & 5.876 & 5.805 \\
\hline Canada & 12.301 & 13.324 & 13.395 & 13.105 & 26.387 & 27.107 & 27.465 & 27.033 & 0.867 & 1.172 & 1.311 & 1.108 \\
\hline Denmark & 9.127 & 10.240 & 10.788 & 10.256 & 25.115 & 25.658 & 25.853 & 25.569 & 4.756 & 4.814 & 4.870 & 4.809 \\
\hline Finland & 9.836 & 10.342 & 10.266 & 10.151 & 24.649 & 25.290 & 25.675 & 25.278 & 2.716 & 2.794 & 2.794 & 2.820 \\
\hline France & 12.932 & 13.520 & 13.178 & 13.350 & 27.119 & 27.776 & 28.018 & 27.691 & 4.529 & 4.660 & 4.739 & 4.636 \\
\hline Greece & 10.285 & 12.000 & 12.736 & 11.831 & 24.807 & 24.807 & 25.844 & 25.395 & 4.223 & 4.413 & 4.472 & 4.367 \\
\hline Hungary & 11.427 & 11.703 & 11.901 & 12.063 & 23.910 & 24.388 & 24.792 & 24.481 & 4.744 & 4.744 & 4.717 & 4.750 \\
\hline Italy & 12.539 & 13.408 & 13.403 & 13.298 & 26.956 & 27.630 & 27.738 & 27.508 & 5.209 & 5.264 & 5.322 & 5.262 \\
\hline Japan & 13.723 & 14.664 & 14.626 & 14.462 & 28.165 & 29.124 & 29.214 & 28.928 & 5.651 & 5.841 & 5.858 & 5.802 \\
\hline Netherlands & 10.870 & 11.918 & 11.894 & 11.696 & 25.837 & 26.478 & 26.790 & 26.397 & 5.956 & 6.127 & 6.194 & 6.092 \\
\hline New Zealand & 9.496 & 10.565 & 11.275 & 10.542 & 24.009 & 24.534 & 24.874 & 24.476 & 2.371 & 2.636 & 2.797 & 2.588 \\
\hline Norway & 11.204 & 11.964 & 12.101 & 11.984 & 24.779 & 25.668 & 26.010 & 25.551 & 2.545 & 2.662 & 2.760 & 2.643 \\
\hline South Korea & 9.636 & 13.423 & 13.780 & 13.005 & 24.877 & 26.788 & 27.347 & 26.536 & 5.779 & 6.124 & 6.221 & 6.058 \\
\hline Spain & 11.768 & 12.766 & 13.105 & 12.747 & 26.166 & 26.886 & 27.294 & 26.832 & 4.213 & 4.368 & 4.523 & 4.358 \\
\hline Sweden & 11.273 & 11.661 & 10.806 & 11.564 & 25.613 & 26.061 & 26.384 & 26.031 & 2.976 & 3.069 & 3.121 & 3.041 \\
\hline Switzerland & 11.433 & 11.905 & 11.874 & 11.843 & 25.796 & 26.143 & 26.380 & 26.092 & 5.054 & 5.171 & 5.264 & 5.137 \\
\hline United Kingdom & 12.910 & 13.337 & 12.506 & 12.972 & 27.312 & 27.852 & 28.153 & 27.787 & 5.438 & 5.480 & 5.544 & 5.474 \\
\hline USA & 15.065 & 15.436 & 15.170 & 15.392 & 28.950 & 29.711 & 30.061 & 29.619 & 3.109 & 3.370 & 3.513 & 3.318 \\
\hline
\end{tabular}

The average figure is computed for the period 1970-2009.

Source Computed. 
exists more than $k$ common trends (where rank $(\Sigma \eta)>k)$. In addition, Pedroni $(1999,2004)$ suggests seven tests with the $\mathrm{H}_{0}$ of no cointegration. Four of these statistics are called panel cointegration statistics. These are panel- $v$, panel- $\rho$, and panel-pp which denote the non-parametric variance ratio, PhillipsPerron $\rho$, and Student's $t$ statistics, respectively, while panel-adf is a parametric statistic based on the ADF-statistic. The extra three statistics are called group mean panel cointegration statistics. These are the group- $\rho$, group-pp, and group-adf which correspond to Phillips-Perron $\rho$-statistic, Phillips-Perron $t$-statistic, and the ADF-statistic, respectively. The three statistics allow the modeling of potential heterogeneity across the panel.

The two cointegration tests assume crosssectional independence in the error-term. Such an assumption is unlikely to hold in practice. Westerlund (2007) suggests four panel tests of the $\mathrm{H}_{0}$ of no cointegration, which allows for cross-sectional dependence. The panel tests denoted by Gt and Ga are performed under the alternative hypothesis of panel cointegration, while $\mathrm{Pt}$ and $\mathrm{Pa}$ are performed under the alternative hypothesis that at least one element of the panel is cointegrated. The $\mathrm{H}_{0}$ of no cointegration which assumes that the error-correction term in a conditional error-correction model is equal to zero is tested. If the $\mathrm{H}_{0}$ of no errorcorrection is supported, the $\mathrm{H}_{0}$ of no cointegration is accepted. If the series are cointegrated, causality should run in at least one direction (Engle and Granger 1987).

The panel unit root tests are performed with two different regressions. One regression includes a constant term only, while the other contains both a constant term and a time trend. A macroeconomic series typically exhibits a trend over time and is nonstationary. It is thus more appropriate to consider a regression with a constant and a trend at level form. First-differencing can be used to remove any deterministic trends in the series. Hence, regressions should contain a constant term only. For the sake of comparison, both deterministics are computed. Failure to test for a unit root and cointegration can lead to spurious results. This underlines the importance of performing these vital tests. Let a timeseries variable, say $\mathrm{LALC}_{t}$, be integrated order of $d$, i.e., $L A L C_{t} \sim I(d)$, if it were to be differenced by $d$ times to become stationary.

The ADF unit root statistics for individual countries are reported in Tables 2 and 3. The series tends to support the above-discussed a priori expectation regarding the order of integration expected for Belgium, New Zealand, Sweden, Switzerland, and the United Kingdom. The series for these countries are found to be non-stationary. One major problem arising with time-series tests is the lack of observations over reasonably long periods. As argued by Toda (1995), even 100 observations are not enough to ensure good performance of the time-series tests. These are as a consequence subject to the criticism of low power. One solution is to apply panel data tests which allow for a sizeable increase in testing power of the framework.

In Table 4, the LLC test statistics for both series are presented, where LALC $_{i t} \sim I(0)$ and LGDP $_{i t} \sim I(1)$. However, the LLC assumptions are restrictive. The test is based on the assumption of homogeneity in the autoregressive of order one (AR(1)) coefficients of the ADF specifications. Other tests, controlling for heterogeneity, structural break or cross-sectional dependence are essential to truly evaluate the order of integration of $\mathrm{LALC}_{i t}$ and LGDP ${ }_{i t}$. According to Banerjee et al. (2004), cross-sectional dependence biases the panel data unit root tests towards the alternative hypothesis. The degree of cross-sectional dependence can be studied by examining the pair-wise correlations between changes in the variables (Koedijk et al. 2004). The pair-wise correlations of the first-differences in two series are generally positive and rather large. ${ }^{4}$ For instance, the pair-wise correlation of $\Delta \mathrm{LALC}_{i t}$ between Austria and Italy is 0.5328 and for Belgium and Switzerland, it is 0.59593 . The pair-wise correlations of $\Delta \mathrm{LALC}_{i t}$ range from -0.0890 to 0.9093 . In addition, the pair-wise correlation of $\Delta \mathrm{LGDP}_{i t}$ between Denmark and the Netherlands is 0.5487, while the correlation coefficient between France and Spain is calculated to be 0.7943 . The pair-wise correlation of $\Delta \mathrm{LGDP}_{i t}$ ranges from -0.0619 to 0.8434 . Therefore, cross-sectional dependence has key implications for the testing framework.

IPS (2003) and Hadri (2000) both recommend a test which allows for heterogeneity between groups. Their tests control for cross-sectional dependence using demeaned data. The IPS test has low power in panels with small $T$ (Karlsson and Löthgren 2000), while the reverse is true for the Hadri test (Barhoumi 2005). As shown in Table 5, the IPS generates similar results to the LLC concerning the order of integration. The Hadri test statistics are reported in

\footnotetext{
${ }^{4}$ Detailed results of the pair-wise correlations are available upon request.
} 
Table 2. ADF-Statistics for Individual Countries at Level Form

\begin{tabular}{|c|c|c|c|c|c|c|c|c|}
\hline \multirow[b]{3}{*}{ Countries } & \multicolumn{4}{|c|}{$\mathrm{LALC}_{i t}$} & \multicolumn{4}{|c|}{$\mathrm{LGDP}_{i t}$} \\
\hline & \multicolumn{2}{|c|}{$\begin{array}{l}\text { With Constant and } \\
\text { Without Trend }\end{array}$} & \multicolumn{2}{|c|}{$\begin{array}{l}\text { With Constant and } \\
\text { With Trend }\end{array}$} & \multicolumn{2}{|c|}{$\begin{array}{l}\text { With Constant and } \\
\text { Without Trend }\end{array}$} & \multicolumn{2}{|c|}{$\begin{array}{c}\text { With Constant and } \\
\text { With Trend }\end{array}$} \\
\hline & $\mathrm{ADF}$ & $\rho$ & $\mathrm{ADF}$ & $\rho$ & $\mathrm{ADF}$ & $\rho$ & $\mathrm{ADF}$ & $\rho$ \\
\hline Australia & $-2.376^{\ddagger}$ & 0 & -1.733 & 0 & 0.607 & 0 & -2.343 & $\overline{0}$ \\
\hline Austria & -1.456 & 0 & -2.828 & 0 & -1.114 & 0 & -3.049 & 0 \\
\hline Belgium & -2.059 & 0 & $-4.355^{*}$ & 2 & -1.009 & 0 & -2.696 & 0 \\
\hline Canada & -1.071 & 0 & -2.029 & 0 & -1.094 & 1 & -2.573 & 1 \\
\hline Denmark & $-3.356^{* *}$ & 1 & -2.392 & 1 & -1.071 & 0 & -2.312 & 1 \\
\hline Finland & -1.558 & 1 & -2.454 & 0 & -1.251 & 2 & -2.008 & 2 \\
\hline France & -2.606 & 2 & 0.4360 & 2 & -1.579 & 1 & -1.671 & 1 \\
\hline Greece & -1.382 & 2 & -3.451 & 0 & 0.725 & 0 & -1.168 & 0 \\
\hline Hungary & -2.113 & 0 & -1.886 & 0 & -1.791 & 1 & -2.430 & 1 \\
\hline Italy & -1.657 & 0 & -2.632 & 0 & $-3.296^{* *}$ & 0 & 0.0722 & 0 \\
\hline Japan & -1.597 & 2 & -1.274 & 2 & -2.070 & 1 & 0.809 & 2 \\
\hline Netherlands & -1.350 & 1 & -2.314 & 1 & -0.774 & 1 & -2.072 & 1 \\
\hline New Zealand & -0.805 & 0 & -2.787 & 0 & 0.298 & 1 & $-3.392^{*}$ & 2 \\
\hline Norway & -1.377 & 0 & -2.769 & 0 & -2.356 & 2 & -1.245 & 2 \\
\hline South Korea & -2.109 & 1 & -0.703 & 1 & -2.514 & 0 & 0.087 & 2 \\
\hline Spain & -1.174 & 3 & -1.710 & 0 & -0.447 & 1 & -3.177 & 1 \\
\hline Sweden & -2.502 & 0 & -1.420 & 1 & -0.399 & 2 & $-3.286^{*}$ & 1 \\
\hline Switzerland & -1.921 & 0 & -2.961 & 0 & 0.567 & 2 & $-4.713^{*}$ & 1 \\
\hline United Kingdom & -0.719 & 1 & -0.602 & 1 & -0.595 & 2 & $-3.682 * *$ & 1 \\
\hline USA & -2.369 & 0 & -2.801 & 0 & -0.817 & 2 & -2.772 & 1 \\
\hline
\end{tabular}

To select the order of lag $\rho$, we start with a maximum lag length of three and pare it down as per the Akaike Information Criterion (AIC). There is no general rule on how to choose the maximum lag to start with. The bandwidth and maximum lag length are chosen according to the Bartlett kernel which is equal to $4(T / 100)^{2 / 9} \approx 3$, where $T=40$ (Basher and Westerlund 2008). The MacKinnon (1991) one-sided critical values for the ADF unit root tests with a constant and without a time are $-3.682,-2.972$, and -2.618 at 1,5 , and $10 \%$ significance levels, respectively, while those with a constant and a time trend are $-4.279,-3.556$, and -3.214 , respectively.

Source Computed.

$*, * *$, and ${ }^{\ddagger}$ denote 1,5 , and $10 \%$ significance levels, respectively.

Table 6. These show $\mathrm{LALC}_{i t} \sim I(1)$ while $\mathrm{LGDP}_{i t}$ is integrated of an order higher than one. Following Caner and Kilian (2001), unit root tests for the $\mathrm{H}_{0}$ of stationarity tend to have serious size distortions when the $\mathrm{H}_{0}$ is close to the alternative of a unit root. Moreover, Choi (2001) argues about the loss of power of the LLC and IPS tests when a linear trend is included and proposes some alternative tests. Referring to especially the $Z$ and $L^{*}$ statistics in Table 7 , both series tend to be $I(1)$. Furthermore, endogenous structural breaks can cause a loss in power to reject a unit root even if the trend stationarity alternative is true (Perron 1989). ILT (2005) present a test to account for endogenous structural breaks. As reported in Table 8, both variables are $I(0)$.

However, all these first-generation tests tend to suffer from size distortions and have low power in the presence of cross-sectional dependence (Herwartz and Siedenburg 2008). This can lead to incorrect inference. The IPS, Choi, and Hadri tests control for cross-sectional dependence using demeaned data. Assuming the existence of one common factor with the same effect on all the individuals and as such is rather restrictive. Furthermore, according to Strauss and Yigit (2003), the demeaning of data may not get rid of the size problem. Even the ILT test fails to efficiently allow for cross-sectional dependence as occurs with the test of IPS, Choi, and Hadri. Pesaran (2007) proposes a second-generation test which allows for the presence of more general cross-sectional dependence patterns. To control for cross-sectional dependence, the standard ADF regression models are augmented with the cross-section averages of lagged levels and first-differences of the individual series. This test is based on the averages of the individual cross-sectionally augmented ADF (CADF) statistics and is found to have good size and power properties even when $N$ and $T$ are relatively small. As reported in Table 9, both variables are found to be $I(1)$. Cointegration tests can be carried out. 
Table 3. ADF-Statistics for Individual Countries at First-Difference

\begin{tabular}{|c|c|c|c|c|c|c|c|c|}
\hline \multirow[b]{3}{*}{ Countries } & \multicolumn{4}{|c|}{$\mathrm{LALC}_{i t}$} & \multicolumn{4}{|c|}{$\operatorname{LGDP}_{i t}$} \\
\hline & \multicolumn{2}{|c|}{$\begin{array}{l}\text { With Constant and } \\
\text { Without Trend }\end{array}$} & \multicolumn{2}{|c|}{$\begin{array}{l}\text { With Constant and } \\
\text { With Trend }\end{array}$} & \multicolumn{2}{|c|}{$\begin{array}{l}\text { With Constant and } \\
\text { Without Trend }\end{array}$} & \multicolumn{2}{|c|}{$\begin{array}{c}\text { With Constant and } \\
\text { With Trend }\end{array}$} \\
\hline & $\mathrm{ADF}$ & $\rho$ & $\mathrm{ADF}$ & $\rho$ & $\mathrm{ADF}$ & $\rho$ & $\mathrm{ADF}$ & $\rho$ \\
\hline Australia & $-6.648^{*}$ & 0 & $-6.215^{*}$ & 1 & $-5.371 *$ & 0 & $-5.428^{*}$ & $\overline{0}$ \\
\hline Austria & $-4.711 *$ & 0 & $-4.616^{*}$ & 0 & $-4.829 *$ & 1 & $-4.824 *$ & 1 \\
\hline Belgium & $-5.058 *$ & 0 & $-5.007^{*}$ & 0 & $-6.358^{*}$ & 1 & $-6.290 *$ & 1 \\
\hline Canada & $-7.191 *$ & 0 & $-7.080^{*}$ & 0 & $-3.520 * *$ & 0 & $-3.585 * *$ & 0 \\
\hline Denmark & $-3.499 * *$ & 1 & $-6.627^{*}$ & 0 & $-3.758^{*}$ & 0 & $-3.820 * *$ & 0 \\
\hline Finland & $-8.434 *$ & 0 & $-8.316^{*}$ & 0 & $-3.480^{* *}$ & 1 & $-3.388^{*}$ & 1 \\
\hline France & -2.403 & 2 & $-6.457 *$ & 1 & $-3.907^{*}$ & 0 & $-4.134 * *$ & 0 \\
\hline Greece & $-6.897 *$ & 0 & $-3.645^{* *}$ & 2 & -1.954 & 2 & -1.758 & 2 \\
\hline Hungary & $-4.988 *$ & 0 & $-4.953 *$ & 0 & -2.457 & 0 & -2.444 & 0 \\
\hline Italy & $-6.087 *$ & 0 & $-6.093^{*}$ & 0 & $-4.187^{*}$ & 0 & $-5.352 *$ & 0 \\
\hline Japan & $-6.527^{*}$ & 1 & $-6.678^{*}$ & 1 & -1.823 & 0 & $-3.509^{*}$ & 0 \\
\hline Netherlands & $-7.177 *$ & 1 & $-7.062 *$ & 1 & $-3.210^{* *}$ & 0 & -3.112 & 0 \\
\hline New Zealand & $-5.362 *$ & 3 & $-5.501^{*}$ & 3 & $-4.611 *$ & 3 & $-5.209 *$ & 3 \\
\hline Norway & $-3.573 *$ & 3 & $-3.659^{*}$ & 3 & $-2.996^{* *}$ & 1 & $-3.757 * *$ & 1 \\
\hline South Korea & $-6.928 *$ & 0 & $-7.812^{*}$ & 0 & $-4.301 *$ & 0 & $-5.010 *$ & 0 \\
\hline Spain & -2.047 & 2 & -2.005 & 2 & -2.357 & 0 & -2.240 & 0 \\
\hline Sweden & $-6.219 *$ & 0 & $-6.071^{*}$ & 0 & $-3.176^{* *}$ & 1 & -2.984 & 1 \\
\hline Switzerland & $-7.267 *$ & 0 & $-7.178^{*}$ & 0 & $-4.770^{*}$ & 1 & $-4.922 *$ & 1 \\
\hline United Kingdom & $-9.301 *$ & 0 & $-9.270^{*}$ & 0 & $-3.171 * *$ & 1 & -2.742 & 1 \\
\hline USA & $-4.619^{*}$ & 3 & $-4.549^{*}$ & 3 & $-3.638^{* *}$ & 0 & $-3.680 * *$ & 0 \\
\hline
\end{tabular}

MacKinnon (1991) critical values for the ADF unit root tests with a constant and without a time are $-3.682,-2.972$, and -2.618 at 1,5 , and $10 \%$ significance level, respectively, while those with a constant and a time trend are $-4.288,-3.560$, and -3.216 , respectively. Source Computed.

Table 4. LLC Panel Unit Root Test Statistics

\begin{tabular}{|c|c|c|c|c|c|}
\hline \multirow[b]{2}{*}{ Variables } & \multirow[b]{2}{*}{ Deterministics } & \multicolumn{2}{|c|}{ Level Form } & \multicolumn{2}{|c|}{ First-Difference } \\
\hline & & $t$ Value & $t^{*}$ & $t$ Value & $t^{*}$ \\
\hline $\mathrm{LALC}_{i t}$ & $\begin{array}{l}\text { Constant } \\
\text { Constant }+ \text { trend }\end{array}$ & $\begin{array}{r}-5.750 \\
-11.580\end{array}$ & $\begin{array}{l}-1.6136[0.053]^{*} \\
-2.4869[0.006]^{*}\end{array}$ & $\begin{array}{l}-32.995 \\
-31.139\end{array}$ & $\begin{array}{l}-27.027[0.000]^{*} \\
-22.212[0.000]^{*}\end{array}$ \\
\hline $\mathrm{LGDP}_{i t}$ & $\begin{array}{l}\text { Constant } \\
\text { Constant }+ \text { trend }\end{array}$ & $\begin{array}{l}-4.843 \\
-8.036\end{array}$ & $\begin{array}{c}-1.512[0.065]^{\ddagger} \\
-1.1039[0.135]\end{array}$ & $\begin{array}{l}-19.241 \\
-21.172\end{array}$ & $\begin{array}{l}-13.467[0.000]^{*} \\
-13.561[0.000]^{*}\end{array}$ \\
\hline
\end{tabular}

These statistics are distributed as standard normal as both $N$ and $T$ grow large. Assuming no cross-country correlation and $T$ is the same for all countries, the normalized $t^{*}$ test statistic is computed using the $t$ value statistics. After transformation by factors provided by LLC, the $t^{*}$ tests is distributed standard normal under the $\mathrm{H}_{0}$ of non-stationarity. It is then compared to the 1,5 , and $10 \%$ significance levels with the one-sided critical values of $-2.326,-1.645$, and -1.282 , respectively. The $p$ values are in square brackets.

Source Computed.

In Table 10, the NH panel cointegration test statistics are computed under both the independent and the identically distributed (iid) random walk $(\mathrm{RW})$ errors $(\mathrm{NH}-t)$ and the serially correlated residuals ( $\mathrm{NH}$ adj- $t$ ) assumptions. $\mathrm{H}_{0}$ of no cointegration is rejected under both specifications. Subsequently, the Pedroni cointegration test statistics are computed and presented in Table 11. All these test statistics reveal a clear rejection of $\mathrm{H}_{0}$. Nonetheless, analogous to panel unit root tests, panel cointegration tests can also be affected by the prevalence of crosssectional dependence. The Westerlund cointegration test can effectively control cross-sectional dependence through bootstrapping. This can be considered as a second-generation cointegration test. Table 12 indicates a rejection of $\mathrm{H}_{0}$ when referring to the $\mathrm{Gt}$ and $\mathrm{Pt}$ statistics. In general, a long-run relationship between $\mathrm{LALC}_{i t}$ and $\mathrm{LGDP}_{i t}$ is confirmed. 
Table 5. IPS Panel Unit Root Test Statistics

\begin{tabular}{|c|c|c|c|c|c|c|}
\hline \multirow[b]{2}{*}{ Variables } & \multirow[b]{2}{*}{ Data } & \multirow[b]{2}{*}{ Deterministics } & \multicolumn{2}{|c|}{ Level Form } & \multicolumn{2}{|c|}{ First-Difference } \\
\hline & & & $t$-Bar & $\Psi_{t}$ & $t$-Bar & $\Psi_{t}$ \\
\hline \multirow[t]{4}{*}{$\mathrm{LALC}_{i t}$} & Raw & Constant & -1.916 & $-2.035[0.021]^{* *}$ & -6.223 & $-23.651[0.000]^{*}$ \\
\hline & & Constant + trend & -2.421 & $-1.390[0.082]^{\ddagger}$ & -6.198 & $-21.930[0.000]^{*}$ \\
\hline & Demeaned & Constant & -1.750 & $-1.206[0.114$ & -6.919 & $-27.142[0.000]^{*}$ \\
\hline & & Constant + trend & -2.676 & $-2.785[0.003]^{*}$ & -6.494 & $-23.538[0.000]^{*}$ \\
\hline \multirow[t]{4}{*}{$\operatorname{LGDP}_{i t}$} & Raw & Constant & -1.529 & $-0.107[0.457]$ & -3.663 & $-10.806[0.000]^{*}$ \\
\hline & & Constant + trend & -2.254 & $-0.502[0.308]$ & -4.021 & $-10.098[0.000]^{*}$ \\
\hline & Demeaned & Constant & -1.260 & $1.240[0.892]$ & -4.226 & $-13.637[0.000]^{*}$ \\
\hline & & Constant + trend & -2.061 & $0.546[0.707]$ & -4.611 & $-13.317[0.000] *$ \\
\hline
\end{tabular}

The IPS test statistics are computed as the average ADF-statistics across the sample. These statistics are distributed as standard normal as both $N$ and $T$ grow large. $t$-bar is the panel test based on the ADF-statistics. The lag lengths for the panel test are based on those employed in the univariate ADF test. Critical values for the $t$-bar statistics without trend at 1,5 , and $10 \%$ significance levels are $-1.980,-1.850$, and -1.780 while with inclusion of a time trend, the critical values are $-2.590,-2.480$, and -2.410 , respectively. Assuming no cross-country correlation and $T$ is the same for all countries; the normalized $\Psi_{t}$ test statistic is computed by using the $t$-bar statistics. The $\Psi_{t}$ tests for $\mathrm{H}_{0}$ of joint non-stationarity and is compared to the 1,5 , and $10 \%$ significance levels with critical values of $-2.330,-1.645$, and -1.282 , respectively. The $p$ values are in square brackets.

Source Computed.

Table 6. Hadri Panel Unit Root Test Statistics

\begin{tabular}{|c|c|c|c|c|c|c|}
\hline \multirow[b]{2}{*}{ Variables } & \multirow[b]{2}{*}{ Data } & \multirow[b]{2}{*}{ Deterministics } & \multicolumn{2}{|c|}{ Level Form } & \multicolumn{2}{|c|}{ First-Difference } \\
\hline & & & $Z$ & $p$ value & $Z$ & $p$ value \\
\hline \multirow[t]{4}{*}{$\mathrm{LALC}_{i t}$} & Raw & Constant & 24.8602 & $0.0000 *$ & 0.7167 & 0.2368 \\
\hline & & Constant + trend & 9.7939 & $0.0000 *$ & 2.1768 & $0.0147 * *$ \\
\hline & Demeaned & Constant & 22.3960 & $0.0000 *$ & -1.2840 & 0.9004 \\
\hline & & Constant + trend & 10.0568 & $0.0000 *$ & 1.6709 & $0.0474 * *$ \\
\hline \multirow[t]{4}{*}{$\operatorname{LGDP}_{i t}$} & Raw & Constant & 27.5120 & $0.0000 *$ & 4.1106 & $0.0000^{*}$ \\
\hline & & Constant + trend & 12.6745 & $0.0000 *$ & 3.724 & $0.0001 * *$ \\
\hline & Demeaned & Constant & 24.8446 & $0.0000 *$ & 3.1707 & $0.0008^{* *}$ \\
\hline & & Constant + trend & 13.8067 & $0.0000^{*}$ & 4.8507 & $0.0000 * *$ \\
\hline
\end{tabular}

The $Z$ test is based on the Lagrange Multiplier (LM) tests are based on the average of the $N$ country-specific KPSS LM-statistics (Kwiatkowski et al. 1992) under which the $\mathrm{H}_{0}$ of stationarity is tested. The Bartlett kernel is chosen to be 3 . Heteroskedasticity is controlled while computing the statistics.

Source Computed.

\section{Panel VECM-Based Causality Test}

Next, any causal relationships between refined aluminum consumption and economic growth are investigated. The key question for determining causal relationships is whether income boosts aluminum consumption or aluminum consumption itself is a stimulus for economic growth via indirect channels of effective demand or supply. One of these channels ${ }^{5}$ can be the degree of urbanization. For instance, as urban centers grow, the demand for more housing tends to rise, and this in turn boosts

\footnotetext{
${ }^{5}$ Subject to data availability, other instruments such as consumption of durable goods (e.g., appliances) and non-durables (e.g., packaging), etc., could have been considered.
}

infrastructural demand for goods such as pipes for water, window frames, electricity cables, etc. (Farooki 2010). Thus, the level of urbanization can affect aluminum consumption. However, urbanization can also be connected to economic growth. According to Abdel-Rahman et al. (2006), nations with highly developed infrastructure and advanced technology will tend to be highly urbanized. Urbanization can be used as an instrumental variable (IV) to capture any indirect channel. Table 1 describes the trend of the natural logarithm of population density (LURB) across countries.

Understanding how a change in economic growth affects aluminum consumption is vital in policy formation. It is therefore necessary to examine any causal relationship between these two variables. 


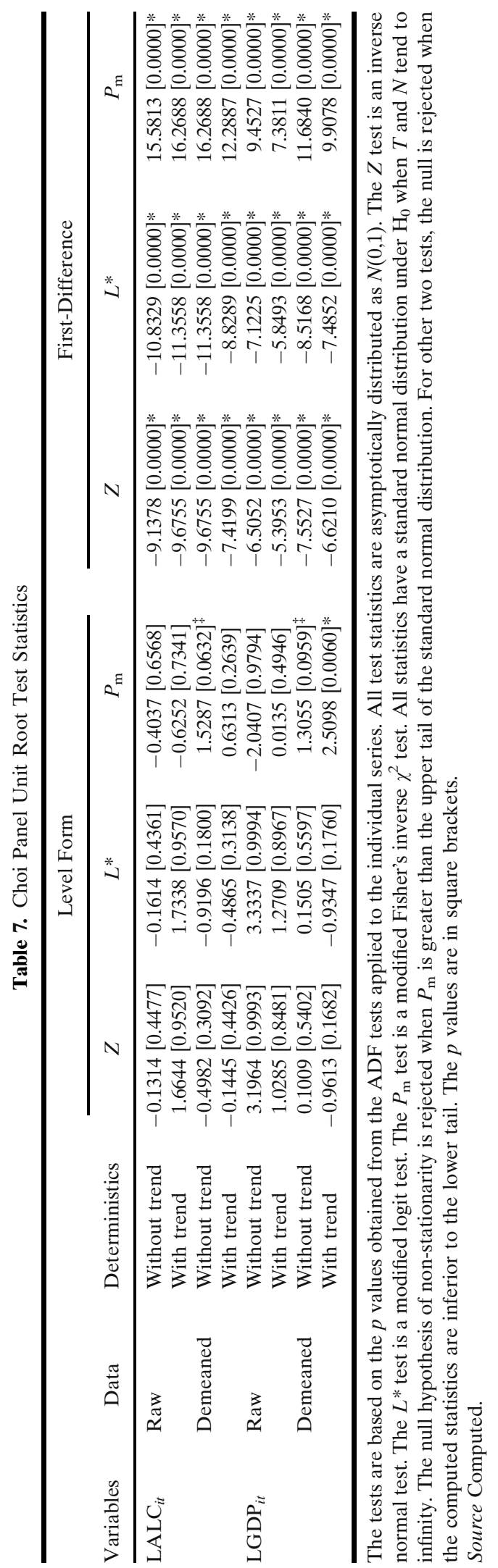

Usually, economic theory offers a basis to construct econometric models and to empirically test them. However, support from the theoretical point of view may not be sufficiently available. As such, one methodology which has been extensively applied in the literature is the Granger causality test. Indeed, as stated by Farr et al. (1998), “... Granger results do provide valuable information that can aid in the development of new theories or in the refinement of existing ones." A Granger causality test requires the variables to be stationary. Hence, an ECM-based VAR causality test which makes use of the firstdifferenced stationary data will be performed. This also allows for the investigation of any short- or longrun causal relationship.

The $\rho$ th order of the panel VECM structure for the causality test (Jaunky 2011) can be represented as follows:

$$
\begin{aligned}
{\left[\begin{array}{c}
\Delta \mathrm{LALC}_{i t} \\
\Delta \mathrm{LGDP}_{i t}
\end{array}\right]=} & {\left[\begin{array}{l}
\alpha_{1} \\
\alpha_{2}
\end{array}\right]+\sum_{k=1}^{\rho}\left[\begin{array}{ll}
\beta_{11 k} & \beta_{12 k} \\
\beta_{21 k} & \beta_{22 k}
\end{array}\right]\left[\begin{array}{l}
\Delta \mathrm{LALC}_{i t-i} \\
\Delta \mathrm{LGDP}_{i t-i}
\end{array}\right] } \\
& +\left[\begin{array}{l}
\phi_{1} \\
\phi_{2}
\end{array}\right]\left[\mathrm{ECM}_{i t-1}\right]+\left[\begin{array}{l}
\varepsilon_{1} \\
\varepsilon_{2}
\end{array}\right]
\end{aligned}
$$

where $i=1, \ldots, N ; t=\rho+2, \ldots, T$; The $\alpha \mathrm{s}, \beta_{k} \mathrm{~s}$, and $\varphi \mathrm{s}$ are parameters to be estimated. $\mathrm{ECM}_{i t-1}$ represents the one period lagged error-term derived from the cointegrating vector and the error-terms $\varepsilon_{1}$ and $\varepsilon_{2}$, are serially independent with mean zero and finite covariance matrix. Given the use of a VAR structure, all variables are treated as endogenous variables. A simple Wald test for joint significance can be conducted to determine the direction of any causal relationship between the two variables. The results from this test should be interpreted as indicating whether prior changes in one variable contribute (or do not contribute) significantly to the prediction of the future value of the other variable. In this case, economic growth does not Grangercause aluminum consumption if and only if all of the coefficients $\beta_{12 k} ; \forall=1, \ldots, \rho$ are not significantly different from zero in Eq. 3. The dependent variable reacts only to short-term shocks. In the same way, aluminum consumption does not Granger-cause economic growth in the short-run if and if all of the coefficients $\beta_{21 k} ; \forall=1, \ldots, \rho$ are not significantly different from zero. These are referred to as the "short-run Granger causality" tests. The coefficients on the ECTs represent how fast deviations from the long-run equilibrium are eliminated. Another 
Table 8. ILT Panel LM Unit Root Test Statistics

\begin{tabular}{lccr}
\hline Variables & Without Break & With One Break & With Two Breaks \\
\hline LALC $_{i t}$ & $-4.576^{*}$ & $-8.929^{*}$ & $-10.997^{*}$ \\
LGDP $_{i t}$ & $-3.056^{*}$ & $-7.128^{*}$ & $-8.108^{*}$ \\
\hline
\end{tabular}

Critical values for the LM panel unit root test (without or with breaks) are distributed asymptotic standard normal and are $-2.326,-1.645$, and -1.282 at the 1,5 , and $10 \%$ levels, respectively. The minimum LM unit root test which accounts for a break in the data is employed to test for the $\mathrm{H}_{0}$ of non-stationarity. Time dummies are included when performing the panel unit root test in the presence of one structural break. The Bartlett kernel is used for the maximum lag length.

Source Computed.

Table 9. Pesaran CADF Panel Unit Root Test Statistics

\begin{tabular}{|c|c|c|c|c|c|}
\hline \multirow[b]{2}{*}{ Variables } & \multirow[b]{2}{*}{ Deterministics } & \multicolumn{2}{|c|}{ Level Form } & \multicolumn{2}{|c|}{ First-Difference } \\
\hline & & $t$-Bar & $Z$ & $t$-Bar & $Z$ \\
\hline $\mathrm{LALC}_{i t}$ & $\begin{array}{l}\text { Constant } \\
\text { Constant }+ \text { trend }\end{array}$ & $\begin{array}{l}-2.572 \\
-2.507\end{array}$ & $\begin{array}{l}-3.815[0.000]^{*} \\
-0.849[0.198]\end{array}$ & $\begin{array}{l}-5.286 \\
-5.243\end{array}$ & $\begin{array}{l}-16.726[0.000]^{*} \\
-14.753[0.000]^{*}\end{array}$ \\
\hline $\mathrm{LGDP}_{i t}$ & $\begin{array}{l}\text { Constant } \\
\text { Constant }+ \text { trend }\end{array}$ & $\begin{array}{l}-1.874 \\
-2.051\end{array}$ & $\begin{array}{r}-0.493[0.311] \\
1.467[0.929]\end{array}$ & $\begin{array}{l}-4.287 \\
-4.639\end{array}$ & $\begin{array}{l}-11.975[0.000]^{*} \\
-11.686[0.000]^{*}\end{array}$ \\
\hline
\end{tabular}

The Pesaran CADF test of the $\mathrm{H}_{0}$ of non-stationarity is based on the mean of individual DF (or ADF) $t$-statistics of each unit in the panel. To remove the cross dependence, the standard DF (or ADF) regressions are augmented with the cross-sectional averages of lagged levels and first-differences of the individual series (CADF-statistics). Critical values for the $t$-bar statistics without and with trend at 1,5 , and $10 \%$ significance levels are $-2.360,-2.200$, and -2.110 ; and $-2.850,-2.710$, and -2.630 , respectively. Assuming cross-sectional dependence and $T$ is the same for all countries. The normalized $Z$ test statistic is computed using the $t$-bar statistics. The $Z$ test statistic is compared to the 1 , 5 , and $10 \%$ significance levels with the one-sided critical values of $-2.326,-1.645$, and -1.282 , respectively.

Source Computed.

Table 10. Nyblom-Harvey Panel Cointegration Test Statistics

\begin{tabular}{llll}
\hline Specifications & Statistics & LAINT & LGDP \\
\hline Fixed-Effects & NH- $t$ & $10.8162^{*}$ & $11.2894^{*}$ \\
& NH adj- $t$ & $22.4711^{*}$ & $20.8405^{*}$ \\
Fixed-Effects and Time Trends & NH- $t$ N & $10.8792^{*}$ & $11.3603^{*}$ \\
& NH adj- $t$ & $28.5619^{*}$ & $24.8268^{*}$ \\
\hline
\end{tabular}

The $\mathrm{H}_{0}$ of the test is no cointegration $\left(\mathrm{H}_{0}: \operatorname{rank}(\operatorname{var}-\mathrm{cov})=K=0\right)$ against the alternative hypothesis of cointegration $\left(\mathrm{H}_{1}\right.$ : rank $(\operatorname{var}-$ $\operatorname{cov})=K \neq 0$ ). $\mathrm{H}_{0}: 0$ common trends among the 36 series in the panel. $N H$ - $t$ the test is performed under the hypothesis of iid errors, $N H$ $a d j-t$ errors are allowed to be serially correlated and the test is performed using an estimate of the long-run variance derived from the spectral density matrix at frequency zero. The number of lags of the non-parametric adjustment for long-run variance is equal to 2 . No model needs to be estimated as the test is based on the rank of covariance matrix of the disturbances resulting from the multivariate random walk. Critical values for the $t$-bar statistics without and with trend at 1, 5, and 10\% significance levels are 5.1142, 4.4957, and 4.1794; and $1.8425,1.5798$, and 1.6651 , respectively.

Source Computed.

channel of causality can be investigated by testing the significance of the ECTs. This test is known to as the "long-run Granger causality" tests.

The direction of causality between aluminum consumption and economic growth has significant policy implications. If there is no causality, then adopting a conservative resource policy measures to limit the consumption of aluminum can be implemented, without the concern of negatively impacting on economic growth. A fall in aluminum consumption can lead aluminum smelting industries to cut down production. This will eventually cause a reduction in the exploitation of natural resources and environmental degradation. This will cause a decline in the utilization of energy, such as electricity. If causality runs from economic growth to aluminum consumption, then environmental and resource policies can be implemented. For instance, 
carbon taxes and tariffs can be imposed on the aluminum smelting industries. These policies will have no impact on economic growth. However, if a unidirectional causality running from aluminum consumption to economic growth exists, then resource conservation policies will have an adverse impact on economic growth.

Conventional ordinary least squares (OLS), fixed-effects, or even random-effects methods tend to yield biased results due to the correlation between the lagged dependent variables and the errorterms. In order to specify the correlation and endogeneity problems, Arellano and Bond (1991) propose a two-step difference GMM method. In the first step, the residuals are assumed to be independent and homoskedastic. In the second step, the first step residuals are used to build consistent inference of variances and covariances matrixes while the

Table 11. Pedroni Panel Cointegration Test statistics

\begin{tabular}{lcr}
\hline Statistics & Without Trend & With Trend \\
\hline Panel- $v$ & $7.59820^{*}$ & $4.54019^{*}$ \\
Panel- $\rho$ & $-6.76174^{*}$ & $-5.53981^{*}$ \\
Panel-pp & $-5.09093^{*}$ & $-5.54941^{*}$ \\
Panel-adf & $-4.54669^{*}$ & $-4.90893^{*}$ \\
Group- $\rho$ & $-5.73334^{*}$ & $-3.84260^{*}$ \\
Group-pp & $-5.14180^{*}$ & $-5.23626^{*}$ \\
Group-adf & $-4.77304^{*}$ & $-4.75988^{*}$ \\
\hline
\end{tabular}

The panel statistics are the within-dimension statistics while group statistics are between-dimension ones. These are one-sided standard normal test with critical values of 1,5 , and $10 \%$ given by $-2.326,-1.645$, and -1.282 . A special case is the panel- $v$ statistic which diverges to positive infinity under the alternative hypothesis. Rejection of the $\mathrm{H}_{0}$ of no cointegration requires values larger than $2.326,1.645$, and 1.282 at 1,5 , and $10 \%$ significance level, respectively. The critical values for the mean and variance of each statistic are obtained from Pedroni (1999). $\mathrm{H}_{0}$ corresponds to no cointegration.

Source Computed. former assumptions are relaxed. For the instruments to be valid there should not be serial correlation in $\varepsilon_{1}$ and $\varepsilon_{2}$. The optimal lag length, $\rho$, is selected until no serial correlation is found in the residuals. For disturbances to be serially uncorrelated there should be evidence of significant negative first-order serial correlation and no evidence of second-order correlation in the differenced residuals. However, the Arellano-Bond two-step GMM procedure does not work well internal instruments. When the lag of the dependent variable and the explanatory variables is persistent over time, lags of the levels of these variables are weak instruments for the equation in differences (Alonso-Borrego and Arellano 1999; Blundell and Bond 1998).

Arellano and Bover (1995) and Blundell and Bond (1998) advocate the two-step system GMM estimator because it has superior finite-sample properties. This estimator is a linear combination of the levels and differences and the weight specified to the levels estimators grows in the event of weak instruments due to high persistency in the series. In the presence of heteroskedasticity and serial correlation, the two-step GMM employs a consistent estimate of the weighting matrix, exploiting the residuals from the one-step estimator (Davidson and Mackinnon 2004). The former is more efficient than the one-step estimator. Yet, the former converges slowly to its asymptotic distribution, while its standard errors tend to be biased downwards for finite samples, in contrast to the one-step estimator. A solution is to use the finite-sample correction to the two-step covariance matrix (Windmeijer 2005). Thus, the two-step approach can still be considered.

The two-step system GMM allows for the use of IVs. Population density is used as a proxy to capture the level of urbanization (Hong and Chin 2007). In addition, time dummies are also employed as IVs to

Table 12. Westerlund Panel Cointegration Test statistics

\begin{tabular}{|c|c|c|c|c|c|c|c|c|}
\hline \multirow[b]{2}{*}{ Statistics } & \multicolumn{4}{|c|}{ Without Trend } & \multicolumn{4}{|c|}{ With Trend } \\
\hline & Value & $Z$ & $p$ Value & Robust $p$ Value & Value & $Z$ & $p$ Value & Robust $p$ Value \\
\hline $\mathrm{Gt}$ & -1.717 & -3.185 & $0.001^{*}$ & $0.002 *$ & -2.899 & -2.932 & $0.002 *$ & $0.011^{* *}$ \\
\hline $\mathrm{Ga}$ & -4.202 & -0.393 & 0.347 & 0.197 & -10.492 & 0.999 & 0.841 & 0.541 \\
\hline $\mathrm{Pt}$ & -5.196 & -2.495 & $0.006^{* *}$ & $0.083^{*}$ & -12.789 & -3.821 & $0.000^{*}$ & $0.044^{* *}$ \\
\hline $\mathrm{Pa}$ & -2.182 & -1.786 & $0.037 * *$ & 0.194 & -11.252 & -1.692 & $0.045^{* *}$ & 0.162 \\
\hline
\end{tabular}

All these statistics are distributed standard normally. Critical values of one-sided tests for 1,5 , and $10 \%$ significance levels are -2.326 , -1.645 , and -1.282 , respectively. The lag and lead lengths are set to one. Choosing too many lags and leads can result in a deterioration of the small-sample properties of the test. To control for cross-sectional dependence, robust critical values is obtained through 5,000 bootstrap replications.

Source Computed. 
control for cross-sectional dependence (Roodman 2009). The IVs are assumed to be correlated with the regressors but uncorrelated with $\varepsilon_{1}$ and $\varepsilon_{2}$. Referring to the over-identifying restrictions, both the Hansen (1982) $J$ test and the Sargan (1958) test are conducted. These tests test for the joint validity of the instruments to confirm whether the model specification is correct. The Sargan test is not robust to heteroskedasticity or autocorrelation while the Hansen test is. Using too many instruments can cause these tests to be weak. Too many weak instruments can overload the endogenous variables and decrease the accuracy of the Sargan and Hansen tests (Roodman 2009). A rule of thumb is to maintain the number of instruments at less than or equal to the number of groups (Docquier et al. 2011). Thus, the number of instruments used is set to 20 , which is equivalent to the number of groups in the panel.

As shown in Table 13, negative first-order serial correlation in the disturbances is discovered in the first-differenced residuals. No second-order serial correlation is established. These results imply an absence of autocorrelation among disturbances. As per the above discussion, the lag order $\rho$ of the panel VECM-based causality tests is computed to be one. The Hansen test statistic for the aluminum consumption equation is 0.296 , while for the economic growth equation, it is 0.232 . These generally adhere to the proposition of Roodman (2009), whereby the telltale sign of valid instruments is a high $p$ value of the Hansen $J$ statistic of 0.25 . The $\mathrm{H}_{0}$ of valid instruments in use is therefore accepted. It is equally essential to check the validity of subsets instruments at levels and differenced instruments. The difference-in-Hansen test of exogeneity is conducted under the null that the instruments in use are proper instruments, i.e., they are exogenous. The test assesses the system GMM with and without a subset of instruments to allow investigation about the validity of such subset of instruments, while considering their contribution to the rise in the Hansen $J$ test statistic. These are denoted as the "Hansen Test Excluding Group" and "Difference (null $\mathrm{H}=$ exogenous)," respectively, under specific sub-headings. The $\mathrm{H}_{0}$ of exogeneity of any system GMM instruments, used such as levels and differenced instruments, cannot be rejected.

Unidirectional causality running from aluminum consumption to economic growth is uncovered in the short-run, while economic growth is found to Granger-cause aluminum consumption in the longrun. A change in economic growth has an impact on aluminum consumption for individual high-income countries such as Australia, Austria, Belgium, etc., as well as for the panel as a whole in the long-run.

Table 13. Blundell-Bond System GMM Panel VAR Causality Test

\begin{tabular}{lll}
\hline Variables & \multicolumn{1}{c}{$\Delta \mathrm{LALC}_{i t}$} & $\Delta \mathrm{LGDP}_{i t}$ \\
\hline$\Delta \mathrm{LALC}_{i t-1}$ & $0.4427508(0.2699059)$ & $0.0717245(0.0294157)^{* *}$ \\
$\Delta \mathrm{LGDP}_{i t-1}$ & $0.6644224(1.227443)$ & $0.544312(0.1610004)^{*}$ \\
$\mathrm{ECT}_{i t-1}$ & $-0.1621966(0.0798776)^{* *}$ & $-0.0355584(0.046684)$ \\
Constant & $-0.0035176(0.0424829)$ & $0.0077492(0.0064156)$ \\
Observations & 740 & 740 \\
Number of Instruments & 20 & 20 \\
Sargan test of over-identifying restrictions & $35.46[0.003]^{*}$ & $69.39[0.000]^{*}$ \\
Hansen test of over-identifying restrictions & $18.49[0.296]$ & $19.74[0.232]$ \\
Difference-in-Hansen test of exogeneity of instrument subsets & & \\
Instruments for levels & & $19.70[0.184]$ \\
Hansen test excluding group & $18.47[0.239]$ & $0.04[0.846]$ \\
Difference (null H = exogenous) & $0.02[0.882]$ & $19.70[0.140]$ \\
Instruments for GMM-style & $18.31[0.193]$ & $0.04[0.981]$ \\
Hansen test excluding group & $0.18[0.913]$ & $-2.56[0.010]^{\ddagger}$ \\
Difference (null H = exogenous) & $-1.90[0.057]^{\ddagger}$ & $0.58[0.564]$ \\
AR(1) test of serial correlation & $1.38[0.166]$ & $5.95[0.0148]^{* *}$ \\
AR(2) test of serial correlation & $0.29[0.5883]$ & $0.58[0.4462]$ \\
Short-run causality test & $4.12[0.0423]^{* *}$ & \\
Long-run causality test & &
\end{tabular}

The model is estimated by the two-step system GMM. The robust standard errors are in parenthesis while p-values are in square brackets. The log of population density and time dummies are used as "IV" instruments. These are not part of the VECM structure (e.g., Mileva 2007). The explanatory variables are assumed to be endogenous and their lags are instrumented in GMM-style (Roodman 2006).

Source Computed. 
Table 14. Long-Run Estimates

\begin{tabular}{l}
\hline \\
\cline { 2 - 3 } \\
\cline { 2 - 3 }
\end{tabular}

Having determined the direction of the causal effects, the long-run impact of income elasticity of aluminum can next be estimated.

\section{Long-Run Elasticities}

Long-run elasticities can be obtained by means of either the fully modified OLS (FMOLS) or dynamic OLS (DOLS) panel data techniques which control for endogeneity, autocorrelation, and heteroskedasticity of residuals. The DOLS tends to outperform the FMOLS estimators in term of mean biases (Kao and Chiang 2000). For comparison purposes, both estimators are computed. Given evidence of cross-sectional dependence, the models include common time dummies (Pedroni 2001). As reported in Table 14, the income elasticities computed by the panel FMOLS and DOLS are quite similar. These are 0.45 and 0.44 , respectively. In effect, aluminum is a necessity in the long-run.

\section{CONCLUSION AND POLICY IMPLICATIONS}

The article attempts to examine the link between aluminum consumption and economic growth for 20 rich countries over the period of 19702009. Two generations of panel unit root and cointegration tests are applied. Both series are found to be $I(1)$ cointegrated especially after controlling for cross-sectional dependence. A panel causality test in a VECM setting is next conducted using the Blundell-Bond system GMM. Unidirectional causality from aluminum consumption to real GDP is found in the short-run while real GDP is found to Granger-cause aluminum consumption in the long-run.
Moreover, a $1 \%$ rise in real GDP causes a $0.44 \%$ rise in aluminum consumption in the long-run for the whole panel.

The prevalence of a long-run causal effect running from economic growth to aluminum consumption and a positive long-run income elasticity points to the importance of economic growth in driving the demand for aluminum. The absence of feedback effects reveals the importance of growth of real income in stimulating the demand for aluminum. These results are consistent with those of Ghosh (2006) and Huh (2011). In similar fashion, they have important implications for environmental and natural resource policies. For instance, various market actors and stakeholders can use these findings to make long-run assessments of aluminum consumption which is intrinsically linked with economic growth.

The aluminum sector is facing major challenges. Many smelting industries rely on power plants producing electricity via carbon-intensive input materials such as coal. There is thus a pressing a need for some form of government intervention. While the imposition of a carbon tax may be a solution to these ecologically harmful manufacturing practices, this can lead to smelter redundancy due to the rise in production cost. Job losses are another potential outcome. ${ }^{6}$ Although the effect of a fall in aluminum consumption arising from a carbon tax may have only short-run impacts, policies should be enacted to preserve the future of the industry. For instance, many high-income countries, such as the European

\footnotetext{
${ }^{6}$ Rio Tinto has been forced to reduce its aluminium production due to the rise in cost arising from carbon tax although it claims to be using clean technology. More details are available online at http://www.themercury.com.au/article/2011/10/19/269911_tasmanianews.html.
} 
Union (EU) members, have decided to introduce stricter $\mathrm{CO}_{2}$ emission requirements for automobiles (T\&E 2009), which may cause an increase in the demand for aluminum in the future. Aluminum is much lighter than steel, and this would enable cars to reduce fuel consumption and to emit less GHG emissions. It remains one of the most environmentally friendly metals and its recyclability is unlimited. ${ }^{7}$ Government actions should therefore target the relevant externalities as precisely as possible.

\section{ACKNOWLEDGMENTS}

I would like to express my special thanks to Thomas F. Rutherfor and two anonymous referees for their comments and suggestions. Errors, if any, are the author's own solely.

\section{REFERENCES}

Abdel-Rahman, A. N., Safarzadeh, M. R., \& Bottomley, M. B. (2006). Economic growth and urbanization: A cross-section and time-series analysis of thirty-five developing countries. International Review of Economics and Business, 53(3), 334 348.

Alonso-Borrego, C., \& Arellano, M. (1999). Symmetrically normalized instrumental-variable estimation using panel data. Journal of Business \& Economic Statistics, American Statistical Association, 17(1), 36-49.

Arellano, M., \& Bond, S. (1991). Some tests of specification for panel data: Monte Carlo evidence and an application to employment equations. Review of Economic Studies, 58(2), 277-297.

Arellano, M., \& Bover, O. (1995). Another look at the instrumental variables estimation of error-components models. Journal of Econometrics, 68(1), 29-51.

Banerjee, A., Marcellino, M., \& Osbat, C. (2004). Some cautions on the use of panel methods for integrated series of macroeconomic data. Econometrics Journal, 7(2), 322-340.

Barhoumi, K. (2005). Long run exchange rate pass-through into import prices in developing countries: An homogeneous or heterogeneous phenomenon? Economics Bulletin, 6(14), $1-12$.

Basher, S. A., \& Westerlund, J. (2008). Is there really a unit root in the inflation rate? More evidence from panel data models. Applied Economics Letters, 15(3), 161-164.

Blundell, R., \& Bond, S. (1998). Initial conditions and moment restrictions in dynamic panel data models. Journal of Econometrics, 87(1), 115-143.

Caner, M., \& Kilian, L. (2001). Size distortions of tests of the null hypothesis of stationarity: Evidence and implications for the PPP debate. Journal of International Money and Finance, 20(5), 639-657.

\footnotetext{
${ }^{7}$ More information can be accessed online at http://www. sapagroup.com/en/Company-sites/Sapa-Profiles-UK-Ltd/ Aluminium/Recycling/.
}

Choi, I. (2001). Unit root tests for panel data. Journal of International Money and Finance, 20(2), 249-272.

Davidson, R., \& MacKinnon, J. G. (2004). Econometric theory and methods. New York: Oxford University Press.

Dickey, D. A., \& Fuller, W. A. (1979). Distribution of the estimators for auto-regressive time-series with a unit root. Journal of the American Statistical Association, 74(366), 427431.

Docquier, F., Lodigiani, E., Rapoport, H., \& Schiff, M. (2011). Emigration and democracy. Discussion Paper No. 5496. http://ftp.iza.org/dp5496.pdf.

Engle, R., \& Granger, C. W. J. (1987). Cointegration and error correction: Representation, estimation, and testing. Econometrica, 55(2), 251-276.

Farooki, M. (2010). China's structural demand and commodity super cycle: Implications for Africa. In C. M. Dent (Ed.), China and Africa Development Relations. Routledge Contemporary China Series (pp. 121-142). Abingdon: Routledge.

Farr, W. K., Lord, R. A., \& Wolfenbarger, J. L. (1998). Economic freedom, political freedom and economic well-being: A causality analysis. Cato Journal, 18(2), 247-262.

Ghosh, S. (2006). Steel consumption and economic growth: Evidence from India. Resources Policy, 31(1), 7-11.

Greene, W. H. (1993). Econometric analysis (2nd ed.). New York: Macmillan Publishing Company.

Hadri, K. (2000). Testing for stationarity in heterogeneous panel data. The Econometrics Journal, 3(2), 148-161.

Hansen, L. (1982). Large sample properties of generalized method of moments estimators. Econometrica, 50(3), 10291054.

Herwartz, H., \& Siedenburg, F. (2008). Homogenous panel unit root tests under cross sectional dependence: Finite sample modifications and the wild bootstrap. Computational Statistics \& Data Analysis, 53(1), 137-150.

Hong, J., \& Chin, T. H. (2007). Modeling the location choices of foreign investments in Chinese logistics industry. China Economic Review, 18(4), 425-437.

Huh, K.-S. (2011). Steel consumption and economic growth in Korea: Long-term and short-term evidence. Resources Policy, 36(2), 107-113.

Im, K.-S., Lee, J., \& Tieslau, M. (2005). Panel LM unit root tests with level shifts. Oxford Bulletin of Economics and Statistics, 67(3), 393-419.

Im, S. K., Pesaran, M. H., \& Shin, Y. (2003). Testing for unit roots in heterogeneous panels. Journal of Econometrics, 115(1), 53-74.

Jaunky, V. C. (2011). Fish exports and economic growth: The case of SIDS. Coastal Management, 39(4), 377-395.

Kao, C., \& Chiang, M.-H. (2000). On the estimation and the inference of a cointegrated regression in panel data. In B. H. Baltagi (Ed.), Advances in econometrics (Vol. 15, pp. 179222). Amsterdam: Elsevier.

Karlsson, S., \& Löthgren, M. (2000). On the power and interpretation of panel unit root tests. Economics Letters, 66(3), 249-255.

Koedijk, K. G., Tims, B., \& van Dijk, M. A. (2004). Purchasing power parity and the euro area. Journal of International Money and Finance, 23(7-8), 1081-1107.

Kwiatkowski, D., Phillips, P., Schmidt, P., \& Shin, Y. (1992). Testing the null hypothesis of stationarity against the alternative of unit root. Journal of Econometrics, 54(1-3), 159178.

Labson, B. S., \& Crompton, P. L. (1993). Common trends in economic activity and metals demand: Cointegration and the intensity of use debate. Journal of Environmental Economics and Management, 25(2), 147-161.

Levin, A., Lin, C.-F., \& Chu, J. C.-S. (2002). Unit root tests in panel data: Asymptotic and finite sample properties. Journal of Econometrics, 108(1), 1-24. 
MacKinnon, J. G. (1991). Critical values for cointegration tests. In R. Engle \& C. W. J. Granger (Eds.), Long run relationships: Reading in cointegration (pp. 1-16). Oxford University Press.

Menzie, W. D., Barry, J. J., Bleiwas, D. I., Bray, E. L., Goonan, T. G., \& Matos, G., (2010). The global flow of aluminum from 2006 through 2025: U.S. Geological Survey Open-File Report 2010-1256, 73 pp. http://pubs.usgs.gov/ofr/2010/1256/.

Mileva, E. (2007) Using Arellano-Bond dynamic panel GMM estimators in Stata. Economics Department, Fordham University, New York, http://www.fordham.edu/economics/ mcleod/Elitz-UsingArellano \% E2\% 80\%93BondGMME stimators.pdf.

Nelson, M. C., \& Donggyu, S. (2003). Cointegration vector estimation by panel dols and long-run money demand. Oxford Bulletin of Economics, 65(5), 665-680.

Nyblom, J., \& Harvey, A. (2000). Test of common stochastic tends. Econometric Theory, 16(2), 176-199.

Pedroni, P. L. (1999). Critical values for cointegration tests in heterogeneous panels with multiple regressors. Oxford Bulletin of Economics and Statistics, 61(4), 653-670.

Pedroni, P. (2001). Purchasing power parity tests in cointegrated panels. The Review of Economics and Statistics, 83(4), 727-731.

Pedroni, P. L. (2004). Panel cointegration; asymptotic and finite sample properties of pooled time series tests with an application to the purchasing power parity hypothesis. Econometric Theory, 20(3), 597-625.

Perron, P. (1989). Great crash, the oil price shock, and the unit root hypothesis. Econometrica, 57(6), 1361-1401.

Pesaran, H. M. (2007). A simple panel unit root test in the presence of cross-section dependence. Journal of Applied Econometrics, 22(2), 265-312.

Roberts, M. C. (1990). Predicting metal consumption. Resources Policy, 16(1), 56-73.

Roodman, D. (2006). How to Do xtabond2: An introduction to "Difference" and "System" GMM in Stata, Working Papers
103 Center for Global Development. http://repec.org/nasug 2006/howtodoxtabond2.cgdev.pdf.

Roodman, D. (2009). A note on the theme of too many instruments. Oxford Bulletin of Economics and Statistics, 71(1), $135-158$.

Sargan, J. (1958). The estimation of economic relationships using instrumental variables. Econometrica, 26(3), 393-415.

Strauss, J., \& Yigit, T. (2003). Shortfalls of panel unit root testing. Economic Letters, 81(3), 309-313.

T\&E. (2009). Reducing CO2 Emissions from New Cars: A Study of Major Car Manufacturers' Progress in 2008. www.transportenvironment.org/Publications/prep_hand_out/ lid:549.

Tilton, J. E. (1989). The new view of minerals and economic growth. Economic Record, 65(190), 265-278.

Toda, H. Y. (1995). Finite sample performance of likelihood ratio tests for cointegrating ranks in vector autoregressions. Econometric Theory, 11(5), 1015-1032.

Turton, H. (2002). The aluminium smelting industry structure, market power, subsidies and greenhouse gas emissions. The Australia Institute, Discussion Paper Number 44. https://www.tai.org.au/documents/dp_fulltext/ DP44.pdf.

Westerlund, J. (2007). Testing for error correction in panel data. Oxford Bulletin of Economics and Statistics, 69(6), 709-748.

Windmeijer, F. (2005). A finite sample correction for the variance of linear efficient two-step GMM estimators. Journal of Econometrics, 126(1), 25-51.

Wooldridge, J. M. (2002). Econometric analysis of cross section and panel data. Cambridge, MA: MIT Press.

World Bureau of Metal Statistics. Annual. Metal Statistics. Ware. England: World Bureau of Metal Statistics.

World Development Indicators CD-ROM. (2011). Washington: The World Bank Group. 